\title{
Research on the Outdoor Environment Design of Kindergarten Based on the Behavior Analysis of Children
}

\author{
Chuanxia Wang ${ }^{1, ~ a}$, Xiaohua Hao ${ }^{2, b}$ \\ ${ }^{1}$ South China Institute of Software Engineering, Guangzhou University, Guangzhou, Guangdong, 510990, \\ China \\ ${ }^{2}$ Guangzhou College of Technology and Business, Guangzhou, Guangdong, 510850, China \\ aemail: 1019493497@qq.com, bemail: 21431031@qq.com
}

Keywords: Kindergarten Design; Environment Design; Outdoor Environment; Behavior of Children

\begin{abstract}
Nowadays people have realized the importance of preschool education and parents are paying increasingly more attention to the development of comprehensive quality of children. However, most kindergartens in China fail to create a good environment, which has been divorced from the development of psychological behavior of children. The all-around quality training of preschool children needs not only the training idea and course system advancing with the terms but also the kindergarten environment aligned with the behavioral characteristics of children to maximize the help of environment to education and achieve the best educational objective.
\end{abstract}

\section{Introduction}

\subsection{Analysis of Characteristics of Cognitive Behavior}

The cognitive development refers to the development of sensation \& perception, attention and memory, and thinking ability and imagination ability of children. Preschool children are in the transition period from the concrete thinking to the logical thinking when their language expression ability and self-cognition ability are improving gradually. Showing a strong tendency of self-centeredness, they begin to realize their gender role clearly.

\subsection{Analysis of Characteristics of Emotional Behavior}

Children's emotional activities mainly manifest as the changes of emotion. Younger children have the weaker control and adjustment ability of emotion. The ability increases with age. Therefore, developing good and healthy emotion in this period has important significance for the future development of personality and character of children.

\subsection{Analysis of Characteristics of Interest Behavior}

The interest is an emotional expression generated in the cognitive activity. Preschool children's interest is mainly limited to the physiological interest with a lack of motivation and thus can shift easily. Besides, there is a variation in different age groups. For instance, the children of $3 \sim 4$ years old like toys with bright colors and stable structures, while the children of $5 \sim 6$ years old like the toys can be detached and assembled with a strong operability.

\subsection{Analysis of Characteristics of Game Behavior}

The game is a special behavior in the growing process of children. In games, children can develop their coordination ability, balance ability, activity skills and physical quality, improve the intelligence and develop the creativity, imagination, language expression ability. Besides, the game helps the forming of sense of group honor, cooperation and other good qualities. 


\section{Design Direction of Kindergarten Aligned with Behavioral Development of Children}

\subsection{Create an Environment for Free Communication}

The communication of children plays an important role in the growth of children. In China, most kindergartens implement a class \& grade system by age, in which case children in different class lack the opportunity of communication. The environment design of modern kindergarten should satisfy the communication need of children and offer a site open for free communication at any time so that children can adapt to the collective life faster and form the habit of social life gradually.

\subsection{Arouse Children's Passion for Game}

Most activities of children are carried out in the form of game. The game is the best way promoting the physical, cognitive, language and emotional development of children. The designer of kindergarten environment should understand the psychological characteristics and behavioral pattern of children deeply to creative rich and diversified space while ensuring the free activities of children.

\subsection{Respect the Character Development of Children}

The outdoor environment design of kindergarten should satisfy the requirements of various activities of kindergarten in terms of spatial organization, architectural form, site division, the texture and color of material, safety, and so on. Respecting the character development of children is good for the development of independent consciousness of children, stimulates children to explore and study consciously and actively, and thus has a good promoting effect on the cognitive and interest development of children.

\section{Design Methods of Outdoor Environment of Kindergarten Aligned with the Behavioral Characteristics of Children}

\subsection{Design of Educational Game Site}

\subsubsection{Design of Animal Feeding \& Planting Area}

A planting area allows children to sow, water and fertilize by themselves and then observe the sprouting and growing process of plant to form the emotion for natural life and get the sense of achievement from the activity. It's suggested to arrange the planting area in the edge of outdoor site to avoid the damage of vigorous activity. Each class should have a small field to improve children's feeling of territory, responsibility and sense of group honor. In the planting area, there should be a passage of about $90 \mathrm{~cm}$ in width between ridges for other children to walk through conveniently.

The kindergarten can offer an area for children to take care of small animals to help children understand how to take care of animals correctly. The animals suitable to be kept in the kindergarten include rabbit, chick, duck, cat, pigeon, and so on, thus creating a communication bridge to the introversive or emotional-disordered children unwilling to communicate with others.

\subsubsection{Design of Area Playing with Water}

Playing with water is very attractive to children, so the kindergarten should offer the suitable outdoor space and site for children by arranging an imitative-ecological stream, pond, pool, spraying tools, and so on, so that children can get various physical properties of water through spraying, splashing and floater.

\subsubsection{Design of Area Playing with Sand}

The sandpit allows children to play various creative games. The process of shaping sand meets children's need of being close to nature and also promotes children's transition from the imaginary thinking to the computational thinking. It's suggested to arrange a water source available for game near the sand playing area because the game combining sand with water is more complex and creative. In the design, laying a section of rough grit or planting a lawn in the road to the sand pit 
can avoid children bringing sand to the classroom. The shape of sand pit should be natural and the large sand pit should be accompanied with facilities like slide or swing.

\subsection{Design of Physical Game Area}

\subsubsection{Design of Climbing Area}

Climbing can strengthen children's muscles in arms and legs and improve the flexibility of body and the coordination of movement. Combining climbing with other game items, we can design a specific area for climbing, such as slide, suspension bridge, wide platform or roomy play house, which will make climbing more attractive. The difficulty level of climbing wall is suitable for the physical ability of children at the age of 3 6, so the wall should not be too high and should have an inclined plane.

\subsubsection{Design of Area for Running, Jumping and Rolling}

The common track in the kindergarten is generally of the simple linear type in which case the sports of running becomes simple and boring and thus fails to meet the need of children's psychological behavioral development characteristics. Therefore, the design of track can retain the slope in the area or build a grassy slope with natural ups and downs artificially so that children can experience the continuous changes of feeling for the environment and space and strengthen their bodies while enjoying running.

\subsubsection{Design of Ground for Ball Games}

According to the statistics of related materials, ball games can arouse children's interest in sports effectively, so children can give full play to their reaction ability, agile ability, coordination ability and cooperation ability while playing balls. The outdoor area for ball games is available for basketball, football, rubber ball, and so on. The football field can be arranged in the lawn area. The storage box of ball should be placed near the ground for the convenience of ball storage.

\subsection{Design of Area for Adventure Game}

\subsubsection{Maze}

The enclosing materials of maze can be hedgerows or boards with the total height of $80 \sim 90 \mathrm{~cm}$. In some part, the height could be $110 \sim 140 \mathrm{~cm}$ to increase the enjoyment of game through the height changes realized by partially and completely blocking. However, the wall should not be too tall otherwise it will hinder the supervision of teacher.

\subsubsection{Tree House}

The tree house is generally built relying on a tree and entered by climbing. The process if full of spirit of adventure and the spatial scale of feeling of territory and the sense of privacy are aligned with the psychological scale of children, so children will feel very comfortable in the space. The design of tree house requires choosing the big tree with strong branches and trunk closer to the ground, and there should be a rope net behind the tree house or a lawn planted or sand with a certain thickness as buffers for falling accident.

\subsubsection{Cave Adventure}

The cave adventure activity can help strengthen children's palms and arms and improve the flexibility of limbs. The unique mysterious atmosphere of cave attracts children to explore. The cement duct and the big tree hole are both good crawling tools for children. To inspire children's desire to explore the space of cave, the crawling space could be a combination of meandering climbing nets of various heights. To avoid becoming the haunt of animals such as snakes or mice, the cavity space should be arranged in a place with good light conditions, the cave should be neither too deep nor too long and there should be not too many plants around the cave. 


\section{Conclusion}

The paper explores the design methods of outdoor environment of kindergarten by analyzing the behavior of children, and puts forward that the vibrant environment design of kindergarten should first respect the idea of children and satisfy their psychological development need and behavioral characteristics. With the objective of promoting the improvement of children's comprehensive quality, the paper offers a specific design idea and design methods for the outdoor environment design of kindergarten.

\section{References}

[1] Mark Dudek. A Design Manual of Schools and Kindergartens [M], translated by Xiuhai Jia \&Xiumei Shi. Wuhan: Huazhong University of Science and Technology. 2008.4.46

[2] Yanqing Guo. Research on Behavior of Children in Scientific Collective Education Activity of Kindergarten [D]. Chengdu: Sichuan Normal University, 2010.

[3] (America) Anita Rui Olds. Child Care Design Guide [M], translated by Xiaoguang Liu. Beijing: China Machine Press. 2008.6.41-504 